\title{
Surfaces
}

\section{Hendrik Birus's "The Archeology of 'Humanism'" Roundtable Discussion}

\section{Hazard Adams, Ernst Behler, Hendrik Birus, Jacques Derrida, Wolfgang Iser, Murray Krieger, Hillis Miller, Ludwig Pfeiffer, Bill Readings, Ching-hsien Wang et Pauline $\mathrm{Yu}$}

Volume 6, 1996

DISCUSSIONS DU PREMIER CONGRÈS INTERNATIONAL SUR LE DISCOURS HUMANISTE

DISCUSSIONS FROM THE FIRST INTERNATIONAL CONFERENCE ON HUMANISTIC DISCOURSE

URI : https://id.erudit.org/iderudit/1064841ar

DOI : https://doi.org/10.7202/1064841ar

Aller au sommaire du numéro

\section{Éditeur(s)}

Les Presses de l’Université de Montréal

ISSN

1188-2492 (imprimé)

1200-5320 (numérique)

Découvrir la revue

Citer ce document

Adams, H., Behler, E., Birus, H., Derrida, J., Iser, W., Krieger, M., Miller, H., Pfeiffer, L., Readings, B., Wang, C.-h. \& Yu, P. (1996). Hendrik Birus's "The Archeology of 'Humanism'": Roundtable Discussion. Surfaces, 6 .

https://doi.org/10.7202/1064841ar
Résumé de l'article

Ces discussions autour du texte de Hendrik Birus, « The Archeology of 'Humanism' », ont eu lieu en avril 1994, dans le cadre du premier Congrès sur le Discours Humaniste. Les communications de cette première réunion du Congrès ont été publiées dans le volume 4 de Surfaces (1994).
Copyright $\odot$ Hazard Adams, Ernst Behler, Hendrik Birus, Jacques Derrida, Wolfgang Iser, Murray Krieger, Hillis Miller, Ludwig Pfeiffer, Bill Readings, Ching-hsien Wang et Pauline Yu, 1996
Ce document est protégé par la loi sur le droit d'auteur. L’utilisation des services d'Érudit (y compris la reproduction) est assujettie à sa politique d'utilisation que vous pouvez consulter en ligne.

https://apropos.erudit.org/fr/usagers/politique-dutilisation/ 


\title{
Hendrik Birus's "The Archeology of 'Humanism'" \\ Roundtable Discussion
}

\author{
Hazard Adams \\ Ernst Behler \\ Hendrick Birus \\ Jacques Derrida \\ Wolfgang Iser \\ Murray Krieger \\ Hillis Miller \\ Ludwig Pfeiffer \\ Bill Readings \\ Ching-hsien Wang \\ Pauline $\mathrm{Yu}$
}

Surfaces Vol. VI.104 (v.1.0A - 12/08/1996) - ISSN:

1188-2492

Copyright for texts published in Surfaces remains the property of authors. However, any further publication should be accompanied by an acknowledgement of Surfaces as the place of initial publication.

\begin{abstract}
This roundtable discussion of "The Archeology of 'Humanism'", Hendrik Birus's contribution to the first International Conference for Humanistic Discourses, was held in April, 1994. The papers of this first meeting of the ICHD have been published in volume 4 of Surfaces (1994).
\end{abstract}

\section{RÉSUMÉ}

Ces discussions autour du texte de Hendrik Birus, "The Archeology of 'Humanism'", ont eu lieu en avril 1994, dans le cadre du premier 
Congrès sur le Discours Humaniste. Les

communications de cette première réunion du

Congrès ont été publiées dans le volume 4 de

Surfaces (1994).

Birus : I wrote this paper originally in the hope that an analysis of the history of the concept 'humanism' will be helpful for us, because I had the feeling that this concept is in no way unambiguous. And so I started with Heidegger's "Humanismus"-Brief, where two meanings of "humanism" are stressed. One, a metaphysical meaning that stresses humanism as concern with the essence of man, and I have tried to present the arguments of Heidegger on page 2-4. And I found that the way the young Marx uses the word "humanism," or with the epithet "positive humanism," is a good example for Heidegger's diagnosis of this concept. And so I think it was not only a tactical step by Heidegger, some months after the end of the Second World War, to begin the discussion of the concept 'humanism' with Marx, but it's really a good and arguable beginning in the analysis of the history of this concept. The other meaning I deal with on page 3 is a culturalist or a pedagogical meaning of "humanism," i.e. not only the appropriation of the human essence, but the appropriation of the human essence in the shape given by late Greek and by Roman authors, and then in the various Renaissances. I follow in part II, beginning with page 5, Heidegger's analysis. He takes seriously the question by Jean Beaufret, how to restore the meaning of the word "humanism." And what he does mainly is a kind of etymologically based speculation on the possible meaning of this term. But I take literally his remark that it's possible, and it could be fruitful, to restore the historical meaning to the word "humanism." And I do it in a way Heidegger didn't do so (and he hadn't the intention to do so), namely, to look in detail at what is the history, what we call in German Begriffsgeschichte, of the concept "humanism." And so in some respect, it was a positive confirmation of Heidegger's diagnosis, but in some respect, it shows in other directions - not really other directions, but other concrete levels of our cultural institutions - where this or these concepts emerged. That is, and I try to show it beginning on page 5, "humanism," especially in German, "Humanismus," is the name of a period. It is nearly synonymously used with the word Renaissance. In Germany, it is often argued that this was a well defined concept of humanism; but then came the journalists, or 
some would-be philosophers, and they have broadened this concept. They used it in a manner that was not legitimate, but quite the opposite. But, if you look at the history, that specific sense of the word "humanism" as the name for a period or an epoch, was in no way its original sense. The forerunner of this historical use of the word "humanism" was the use of the word "humanism" in the sense of "secularism," elaborated in the context of the Young Hegelians, Feuerbach, Ruge, young Marx, and Hess. This was prepared by Hegel or, what is more, in the English Hegel translation I use here, you'll find the word "humanism," but as a mere paraphrase. In the original, you will not find the word "humanism," only the name of the Goethean allegorical person, the Humanus. Originally (and this is a third step back) this term was a pedagogical term, used in the debate on what is the best way of planning high school curricula and such things. That was the first surprise for me. I knew it, but I had forgotten it, that the term "humanism" emerged in the nineteenth century. It's a concept of the nineteenth century. I think it is quite interesting. And the arguments on this page from the $O E D$ that Hillis Miller gave me this morning are completely congruous with this history of the concept in Germany. On page 8, I quote Niethammer, the friend of Schiller, Fichte and of his followers. There you can see the word "humanism" was created with respect to the highly prestigious word humanity. In Germany, that was mainly used by Herder. But only on one page, Niethammer indicates another direction, back to the Renaissance times. He says, humanism is also linked with the "study of the so-called Humaniora," and that goes back to studia humaniora, studia humanitatis, beginning in the fourteenth and fifteenth century. My third step is then to say: well, if the notion of "humanism" emerged in the nineteenth century, let's look for the words "humanist," "humanistic." And that again brings us back to the Renaissance. But it's rather an ugly word; a good Latin scholar never would build such a word, "humanista." It smells like a classroom. This word doesn't have its root in Ancient Greece or prePlatonic times, but in the classrooms, tutorial chairs, the syllabus, and such well institutionalized things of the Renaissance. This was the original use of "humanist," "humanistic," but you can see that this word very quickly became revalorized because it had an etymological link with "humanitas." And so it came into the gravitation of this word "humanitas." I only put the stress on three main components of this ancient concept, on page 10 and 11. The first you can find in the Rhetorica ad Herennium, which was not written by Cicero, but was very close to him: here, "kind, humane behavior" is the 
basic meaning. And then, some years later, with Cicero, as the word for "human nature" as opposed to "bestiality." So in this respect, Heidegger's diagnosis is quite correct, that it has to do with humanitas, and with the specific difference between man and animal. But at the same time, "humanitas" means "human" in opposition to "inhuman," in the sense of "civilized," "well educated," "really human" in an emphatic sense. And the opponents are the barbarians, people who only can say "ba, ba, ba, ba, ba," which was the original sense of "barbarian" in Greek. And so it is closely connected with paideia and it was Aulus Gellius in the Attic Nights who put the stress on this. The last part of my historical review is Medieval Christianity, where "humanitas" is opposited to "divinitas." In the fifteenth century, you still find this opposition, but now it's not a binary opposition, humanitas used as the middle term between "animalitas" or "feritas" and "divinitas," and there the stress is laid on the similarity between man and God. So in Erasmus of Rotterdam, as the main exponent of the later humanism, the word "humanitas" stands for "man's autonomy before God." But here you also see the price for this high prestige of the word "humanity," "humanitas": that it has to do with class differentiation, with quasi-aristocratism, "nobilitas litteraria," and so on. I think all these components we can find in the history of this concept. All these are vivid now, and maybe it's part of the attraction of this word that it is such a Proteus-like word, where you can revivify one component or the other.

I should say some last words to the context I have written this paper. I wrote it recently at Yale, but it has a double context. One is this conference where it may be the most historical paper. The other is a research group on "Humanist Dialogicity" at the University of Munich. Because this deals mainly with the fourteenth, fifteenth, and beginning sixteenth century, my paper will look very modernist in this context. So it might connect these two debates on what could be humanist discourses today and humanist dialogism, in opposition to scholastic monologism and such topics. I think if we plan to have our third meeting in Germany, it could be quite interesting to have a dialogue between these historical oriented humanism scholars and our group that is interested in the place of modern humanities and of humanist dialogue in contemporary and future society.

Iser : What you have outlined is a sample of a specifically German scholarly pursuit: called Begriffsgeschichte, meaning the history of the usage and application of key concepts. The cumbersome English wording is an indication that there is no equivalent in 
Anglo-American scholarship for it.Begriffsgeschichte usually implies (and I think you have given an example), that key concepts can accommodate a diversity of ideologies, and ramified connotations. Simultaneously, they are used in order to endorse authoritatively the very ideas that have been put into it. Thus there is a duality operative in such key terms that have issued into a history of their own. This is borne out by your reference to the third humanism that has engendered, in turn, a fourth humanism that was rampant after the Second World War (Alfred Weber). The concept had an aura that lent itself to what had to be acclaimed. Heidegger was very much aware of what this concept carried in its wake. Although he deconstructed the notion of humanism, he nevertheless dwelt at great length upon it owing to the overriding function it exercised in the postwar years. It is doubtful whether Heidegger would have published his book on 'Humanism', if that term had not be so loaded.

Derrida : Two or three minor contributions to the German Begriffsgeschichte. As far as I remember very vaguely (I don't have my library here either), there is in Fichte's discourse on the German nation a place where he tries to demonstrate that the word "Humanität" is something totally unintelligible to the German primitive speaker. "Menschheit" means "Humanitat" as something, in Latin, something already decadent. When he wants to give an example of what the German speaker immediately understands, he takes this example, "Menschheit," as opposed to "Humanität," one example of these Roman, Latin words which are foreign imports.

Iser : And looked down upon.

Derrida : Yes, of course. So perhaps there is in this tradition, and Fichte is probably not the only one who thinks so, some notion regarding the Latin "humanitas," "Humanität." "Humanität" is something we don't need. We don't need "Humanität; we have "Menschheit." Even an unlearned German immediately understands what Menschheit is about. He doesn't understand Humanität, an abstract, and he opposes abstract concepts to sensible, intuitive understanding of Menschheit. Menschheit is immediately intuitive. Humanität is an abstract construct. So that's one obsevation regarding the German Begriffsgeschichte. Now for the Greek. In Aristotle, this perhaps provides us with the connection to the others, Hillis's others. Aristotle says that God and the animal ignore others. God knows himself and He has no others. And the animal has not the possibility of making decisions, of delivering decisions, so he doesn't have 
others either. So the only being who is able to have a relation is man, between animals and God. He has others. Only man has others. Now, a third and final suggestion about Heidegger. Of course this is an enormous field, and it is difficult in improvising to do justice to these texts. But finally, what does Heidegger say? That precisely this history of the concept - not simply the narrative the Geschichte, the history itself; it's not simply the narrative about the concept, the genealogy, but the real history of the concept - what it misses is finally Menschheit, the humanity of man. What is ignored by this history, metaphysical or theological history, is that Aristotle reduces man to the animal, a rational animal, a rational animal. And this definition man as a rational animal finally misses the point, misses the essence of man, so the whole history of the concept is simply a dissimulation of the essence of man. Which means that the Begriffsgeschichte is also the history of the misinterpretation of man. What this history misses is precisely the essence of man.

Iser : There's a reason why the link between "study" and humanism has been a problem, and hence was subjected to criticism. This relationship was not in keeping with that transcendental entity: "Menschheit".

Derrida : But Heidegger wouldn't call this "transcendental entity," of course.

Iser : No, I'm not talking about Heidegger.

Derrida : Okay, yes, yes.

Birus : I completely agree. Let me only make an additional remark to Fichte. The target of his polemic was probably Herder, who had promoted the word "Humanität" in German, and the late Herder who was such a strong opponent to Kant and Kantianism, (with his Metacritique of the Critique of Pure Reason), and who always put the stress on life and its immediacy. So Fichte makes a turn against him by saying: "This key word humanity, used by Herder is so abstract. But myself, staying in the tradition of Kant, I'm much more concerned with real life and with the popular understanding of this concept of Menschlichkeit, Menschheit." I think these are the social and historical contexts for the opposition Menschheit vs. Humanität elucidated by you.

Behler : Yes, I would like to follow up on you, but first a word about Begriffs geschichte, history of concepts. Of course, history of concepts was used to confirm the 
matter that was investigated. But the history of concepts can also have a destabilizing, undermining effect, and can have even a deconstructive effect if you go into the history of these terms as they originated. I think that this is what Hendrik was indirectly doing, namely, showing us that high-toned terms like "humanism," "humanistic discourse," derive from something very petty, e.g., the classroom atmosphere of the Middle Ages, the Renaissance, and then over centuries assumed status and became terms with which we defend our existence as humanistic scholars, and the humanities. This is another effect of Begriffsgeschichte, and that's how I learned it. Heidegger would never engage in anything as scholarly as Begriffsgeschichte. He thinks he is too high class for that and would leave this to the investigators. He is the metaphysician. He doesn't have to do Begriffsgeschichte. However, what he does in his famous essay on Humanism, the first writing of his after the war, is precisely Begriffs geschichte, the history of a concept, however on a very high level and with an undermining, disillusioning effect, namely, dissolving the grammar of humanism and humanistic discourse. The immediate occasion for this text, as Jacques has shown in Les Fins de l'homme, was of course Sartre, existentialism as humanism, the humanistic trend of post-war Europe. People were trying to find a ground on which they could agree, human existence, human reality.

Derrida : Heidegger tried to show that his own discourse was not inhuman, but hyperhuman.

Behler : Yes. He showed that, first of all, humanism, as it surrounded him, was metaphysical. But he also went into the history not of the the concept, but of the phenomenon. It is very interesting how he starts: the first humanism is not Greek, no it's Roman, because it's already secondary, it's already a classroom humanism. It's already an imitation, because the Greeks were the true humanists. They had existence and they reached out, whereas the Romans were copying an ideal and thereby making it smaller. From then on, you have the sequence of humanisms as Heidegger depicts them. He leaves out one humanism, however, which is interesting to me. This humanism must have been on his mind, and that is the humanism of the age of Goethe, more precisely, of German Idealism, something Jacques will talk about on Thursday. This humanism aims at the harmonious development of all human faculties and is again a metaphysical form of humanism. But in the end, Heidegger is not anti-humanist. Humanism is not enough for him, he wants humanism only on a higher level. 
Derrida : Humanism is not worthy of Dasein.

Miller : It's really setting Dasein against existentialism. When he was asked whether the Sein und Zeit was existentialist, the answer is no, it's super-...

Derrida : Not the same level.

Miller : And what you were saying about the Latin is quite right. Since it's Latin, it's bad.

Behler : It's secondary.

Miller : But Heidegger, Heidegger, on the other hand, will do a kind of Begriffsgeschichte, which takes you back to the Greeks, and then it's another matter. Or with German words, where he will...

Derrida : Nevertheless, nevertheless, he's not completely Greek. Aristotle doesn't escape. Of course, humanism is Latin, but the definition of man as a "Rational animal"... is something already Greek.

Behler : This is of value to our discussion. That's how I read Heidegger's text, although I'm not ready to accept his notion of existence in these late texts. But the questioning he does is inspiring and something we can learn from, namely, the questioning of the institutionalization of humanism, making it something definite, something that can be learned, according to which we model young people. I think here lies his value, and also of the Begriffsgeschichte that Hendrik has attempted on the basis of the work of others and of course on his own.

Krieger : Yes. I suppose in the spirit of everything that's been said so far, the ambiguities in the history of the term and in its present use are possibly overwhelming and often misleading and deceiving, self-deceiving. If we talk about all the meanings, we can't ignore the obvious meanings that are given to the word "humanism," "humanities," "humanistic," by the lay public in this country. When people hear that I'm a humanist or anyone else is a humanist, they somehow confuse it with the word "humanitarian." That is, they take the human element that is emphasized in some parts of your Begriffsgeschichte, they take these human elements, elevate them, isolate them, and somehow they're confused into believing that a humanist is a nice person. 
Readings : If you call yourself a humanist and they'll take it to mean you don't believe in God. Then you're in trouble.

Krieger : No, I'm getting to that. There is this overlay of these several meanings. The ambiguities that come from the fact that the word "human" is there in the term. But then there is in this country also that other meaning that Bill has just referred to: "humanism" is the word, used officially by the religious right. And they're taking some part of the meaning in its history. As a matter of fact, if you look at the $O E D$...

Miller : Yes. Where else.

Krieger : ... and look at the first meaning of "humanist": "Formerly sometimes, a secular writer as distinguished from a divine." And that refers to the distinction made at one point where the distinction is not between the human and the animal, but between the human and the divine - humanitas/divinitas. And that part of it is taken by the fundamentalist right, so that to call someone a humanist is to call him godless, a relativist in values (which means to the right no values)... destructive of all received expectations, and so on and so on. And of course, fundamentally unamerican and ready to destroy the Constitution.

Birus : Also "undeutsch," like the Young Hegelians.

Krieger : Uh huh. That's interesting. So that's another meaning we have. We are speaking of two very different communities, the community that would welcome the humanist as being a nice person who might lead a charity drive, and the fundamentalist right, another community, for whom "humanism" has this distinctly secularist distinction, destructive of all things good, because without religion there is no morality. But then thirdly, when we invented the title for our group and our undertaking, we played right into Heidegger's hands. We were the Romans come again. That is, we were involved in the classroom, the institutional, academic notion of humanistic discourses, which essentially in the Western, at least in the American universities, for decades has meant the family of disciplines. And you have long arguments in many universities about whether history is a humanities. No one quite knows whether history is a humanities or a social science? Philosophy too in some places. Yet we have in this country, as you don't have in les sciences humaines, a rigid distinction between the social sciences and the humanities, which has become 
more rigid as the social sciences have become more quantitative. And you can find someone who would call himself an "old-fashioned sociologist," asking whether he could become a member of the humanities, because he had no home in the social sciences. But the family of disciplines that go under the academic notion of the humanistic... Again, look at the $O E D$. The second meaning of "humanist": "one devoted to or versed in the literary studies called humanities."And then it goes on: "a classical scholar, especially a Latinist; a professor or teacher of Latin."

Readings : Yes, that's litterae humaniores, which I take to be the English version of where this comes from. It originally means "not divine," and then it comes to take on its own meaning.

Krieger : And it does pick up the notion of humanism from the Renaissance, with Erasmus as the great humanist. The translation of the classics being identical with what it was for the Renaissance to be creative. Obviously, when we said "humanistic discourses," we had specific kinds of languages in mind in creating our little family. But this phrase itself is one that is often, these days, under attack. I mean, there are antagonists within the university who would be as unhappy with this phrase as Heidegger might be, associating it somehow with academic "liberalism," within a given tradition, possibly post-nineteenth century German. Reviewers of books will say, "this book is an old-fashioned humanist book," and that means something. It means a certain kind of ideology that is being attributed to the book. And the ideology will somehow be affiliated with some kind of post-Kantian, post-Humboldtian liberal idea of what the university is and what the kinds of discourses are that fit within the framework of what we're supposed to talk about. And so there is an ideological thrust, and it plays a political role in the current structure of the university. And to some extent, if we call ourselves an international conference, or whatever it is, of the humanities, of humanistic discourses, we are in an ideological game. And they'll be people concerned about how exclusionary this might appear to them to be.

Iser : In this respect, what Ernst has suggested in his paper, the German version of Geisteswissenschaften would be a way out.

Krieger : Then you have problems of Geist, as tomorrow Ludwig will be talking about the problem of the Geist and what happens if you substitute culture for Geist. 
Iser : I think Geisteswissenschaft is by far not as loaded as "humanistic;" "Geist," only serves as a common denominator, without implying any kind of spirituality.

Birus : It was so interesting for me that Heidegger, on many points in his "Humanismus"-Brief, could give bibliographical references, but he doesn't like to do so. References he only gives from Greece, from Kant, Hegel. It's quite clear that he refers to Noctes Atticae by Aulus Gellius. So he prefers to give no other reference than to indicate that this late Roman was his point of departure. And on the other hand, I found it strange to speak about the Romans as 'first humanists,' because in the handbooks the Renaissance is named the 'first humanism.' But, as I indicated in a footnote, that identification of Roman humanism with 'first humanism' was nearly unanimously applauded in the early '30s by W. Jaeger, W. Schadewaldt and other experts. Up until now, that first humanism is Roman humanism. So in this point, Heidegger is absolutely not original, but he doesn't like to refer to colleagues in special disciplines.

Derrida : He did so just before the '30s, and then he stopped. I think there is not a single reference, after Sein und Zeit, not a single reference to any living philosopher.

Birus : But he has read them, yes?

Miller : Not even Husserl. Not even a Husserl note?

Birus : Only one further remark to you. There should be a complementary synchronic analysis of the use of the term "humanistic" in academic and non-academic contexts in America. But I think that is not our international problem, because in France and in Germany and so on, we haven't this common denominator.

Krieger : I hope before we're done we will hear something about what do they do with this in East Asia, or do they not do it, or does it appear in any ghostly or any other form?

Miller : I have just two points. One, to return just a bit to the $O E D$, which is my small contribution here. I noticed that under "humane," there is something called the Humane Society, which is the "title of a society for the rescue of drowning persons." Whereas the Humane Society in the United States is for the rescue of... 
Yu : Animals.

Krieger : It's called the animal rescue shelter.

Miller : The quotation comes from Medwin, Angler in Wales, 1834: "The men of the Humane Society... came hurrying, with their apparatus for resuscitation."[ $\underline{1}$ ] That's amazing. Synchronic and diachronic can't really be separated, in the sense that the history of the word remains in its present uses. You can't just say, well, I don't mean it the way they meant it in the sixteenth century, and get away with it. So "humanism" really is, if you take either your German and Latin history, or the one on this page in the $O E D$, a complex word in the Empsonian sense. That is to say, it's a word that has contradictory and clashing meanings that are woven together. The earliest reference to "humanism" is Coleridge, 1812, so the English history confirms yours, whereas "humanist" does go back to the sixteenth century. But not "humanism" as a term. And "humanistic" (as in our phrase, "humanistic discourses"), the earliest example is 1845 . Though the $O E D$ may not always get it right (it's been being revised a lot - its basis was just the little slips of paper people happen to have anded in), nevertheless, it's fairly accurate.

Krieger : Did you notice the use of "humanism" in 1812 by Coleridge?

Miller : That's one of the interesting ones. It means very specifically somebody who believed in the mere humanity of Christ. This person went from Arminianism "to Arianism, and thence to direct Humanism." That is to say, he said, "Christ is just a man, not a God."

Krieger : That fits with the rightwing attitude toward humanists.

Miller : And that meaning already is present in the late nineteenth century in the two quotations under "humanistic," the first from Pater, which from the point of view of our history of the Renaissance is interesting. He says, "The Church was becoming" - and there's a bracket that tells you when (and this is in Marius the Epicurean) - "in the latter part of the second century humanistic, in a best and earliest Renaissance." So for Pater in 1885, the first Renaissance was second century a.d. And it was a Renaissance of the Church. That is to say, there was a movement in the Christian church towards a humanism which Pater saw as the best, probably because it was earliest, but really a very good one. Then the next quotation is Gosse about Pater, and 
what Gosse says about Pater in 1896 is our American idea of the humanist atheist: "With the accession of humanistic ideas, he Pater had gradually lost all belief in the Christian religion." He'd become a humanist in the sense of an atheist. And I was telling Hendrik my story about Yale, that has close connections to the Luce Foundation (Luce being Henry Luce, who was a Yale graduate, very very rich) which sets up professorships. They went to him, they wanted the Luce Foundation to set up a professorship. "Professor of Humanistic Studies" That was, for example, Harold Bloom's title.

Krieger : I didn't know that. In the humanities?

Miller : The Luce Foundation wouldn't do this. Why? Because that meant to them supporting atheism. And they said, we are not going to give money for a chair in atheism. And it was apparently impossible to explain to Henry Luce (attempts were made) that that was not really what was meant, it was not atheism, and so on.

Krieger : Oh, there are many such chairs.

Miller : Oh, sure. Oh, sure, it's a common name, and it doesn't mean anybody is an atheist at all. It was nevertheless understood that way. The other small point I had to make, if I may. To go back to the Menschheit and Humanität, this is our translation problem again. That is to say, a lot is at stake in the use here of the German word, as opposed to a Latin borrowing. Isn't it Fichte who said, "Anybody can philosophize. It's universal, as long as you do it in the German language"?

Derrida : But it's more complicated. He says so, but he says, "Anyone who thinks the way one should think, that is, believes in the eternal development of spirit, he speaks German, even if he's a native speaker in Italian, in English, he speaks German." So German, in that case, doesn't mean German in the usual sense for the linguists. To speak German means to philosophize in that way, to think what Fichte thinks one should think. That is, to believe in the communitive movement of man and spirit. So he makes a distinction between two ways of speaking German. And a German speaker, a native German speaker, if he doesn't think that way, he doesn't speak German. He says, he is not our Geschlecht. He doesn't belong to our family, to our Geschlecht if he doesn't think that way, even if he speaks German, linguistically speaking. So the reference to language is very very profound here, very paralexical. 
Readings : But Jacques, is it not following the idea in the eighteenth century that the French language, in its word order, completely mirrors natural human thinking?

Derrida : Languages are not so perfect as a representation of thinking, but it is true there were some such things, but it was not so powerful as in Germany.

Wang : When Mencius, a third generation Confucian, was talking about human nature, he says, "Human nature is a little different from the nature of the animals." And he stresses the importance that the former is expressed in the power to "sympathize", in an instinct to help. "A boy is dropping into the well, and you want to hold his hand waving for his rescue." That's human nature.

Yu : You may not do it. You may not actually take action, but you will feel the urge.

Miller : Well, that's the Humane Society: rescue a drowning person.

Wang : And it seems to me that of all the definitions of "humanism," except for the first one, the other three are all acceptable in the Chinese tradition. The first one is about Christ, and there's no such a problem in Ancient China, so...

Miller : Would it be the same character? or characters?

Wang : Jen-hsing, these two characters, are for "human nature." Then, they also denote a special kind of studies, a knowledge about human beings, a "humanism" perhaps. No?

Krieger : You don't have a Christ, but is there a humanism, or any like term that suggests that the power of the human is sufficient without divine supplementation?

Wang : Yes, one of the most influential books on Chinese philosophy, ancient philosophy, written in the twentieth Century is called, instead of "History of Chinese Philosophy, theHistory of Chinese Theory of Human Nature. And in the first chapter the author, Professeur Hsü, talks about how the Chinese in ancient days, in the age of Confucius, bid farewell to a society of strong religious or ritualistic practices. And then it turned to the investigation of human nature. 
Yu : But it's also circular. I mean the two are seen as mutually reflective, or fractally related somehow, to each other. Neither is the human an individual, you know, in some absolute sense of the word, nor is humankind something that you can really consider outside of this context in which it's embedded, and, you know, in which you see various reflections, both into nature and back from nature establishing your standards of behavior and everything else.

Krieger : Is the word "human," or any variety of "human," "humanistic," any variety of that involved in the organization of academic discourse?

Wang : Yes, I would say that as easly as the Han dynasty (third century B.C. to A.C third century) a curriculum in humanistic education was established in academic discourse by imperial edict. The classics studied include The Book of Changes, The Book of Songs, and The Book of Rites. History is a subject, too, in the organization of academic discourse.

Krieger : Is poetry, for example, taught in that group? Or is poetry or literature, or whatever you call it, taught as a separate thing? Literature is invariably part of a larger entity, which allows relationships among what kinds of texts we do or don't call "literary," because the humanities captures a great variety of them, and they change places all the time.

Yu : Oh, yes. Well, literature embraces it. You know, it's not belles-lettres until certain moments, later moments in Chinese history. Originally it's all written discourse.

Krieger : And poetry is not taught separately.

Yu : No, it's part of...

Krieger : That's what I mean. It's just part...

Yu : But it is, it's a privileged part...

Krieger : Among?

Yu : Among belles-lettres.

Krieger : Except, is there any interchange among the categories?

Wang : Yes, poetry is quoted in history, and so on and so forth, all the time. Scholars use poetry to prove and substantiate their discourses on diverse subjects. 
Yu : Of course, for some period of time, you would have had to be able to write poetry to be a government official.

Derrida : Isn't there, in Chinese culture or Chinese tradition, something you could translate by "secularization"? A movement called, which would look like, sound like secularization?

Wang : Okay, I had a feeling that the direction Confucius led in the sixth to fifth century B.C. was a hind of "secularization, a departure from...

Yu : But secularization from what?

Derrida : That is my question. When you mentioned humanism or the interest for the human nature, the discourse points to some autonomization of the human as opposed to theology, or religion, or something which would free the study of man from theological assumptions. Or no.

Yu : I don't think so. There is nothing... I mean, that's the one thing that's not there from the very beginning. It is not a binary... It's not being... It's not a binary in relation to some notion of the divine. Now the human is sometimes set in relationship to the natural, the natural human in heaven, or whatever, but it's not a divine...

Derrida : Is it that something like, secularization, whatever we may mean by this word in the West, has no meaning, no chance to occur?

Krieger : Unless it's in the concept of nature, that is, beyond the human.

Yu : It's not a binary.

Pfeiffer : A connection here with modernization, which takes on then the connotations of what used to be secularization in the West.

Readings : I think we should recognize that secularization has to do with history. When you look at the Begriffsgeschichte or at the dictionary and you realize that "humanities," "humanistic," and "humanism" don't mean the same thing and in fact disconnect. And I want to go back (it's like this running thing I have about the Renaissance) to the litterae humaniores; they introduce a notion of historical recovery and of temporal slippage into the human, and the great misrecognition 
that then occurs is belief that this is somehow the ontological search for something that is essentially human, "humanism" in that sense in which, in certain theoretical circles, it gets denounced. That seems to be sort of inaccurate in a way that obscures the fact that to be a "humanist" in the Renaissance sense emerges in the university, not just in the study as a bad place, but in some sense, in the study as a place where a certain problem of intellectual contemporaneity gets faced. To come back to the discussions we were having yesterday, it seems to me if we take seriously the etymology of the notion of humanism, and the etymology of "secularism," for that matter, we recognize that there is a historical aporia that renders being a contemporary intellectual problematic or impossible. In that sense, I sort of said yesterday, I don't know what "humanistic discourse" is. I have a real problem with this title, which is a problem of my stupidity and my idiom. I don't know what a "humanistic discourse" would be. If you were to say "discourses in the humanities," then that has a referent for me and that's fine. I can situate that. But what "humanistic discourse" is, it seems to imply a style, a continuity. There I think that just doesn't work...

Krieger : At the more superficial level?

Yu : You're just not in the academic context.

Krieger : Yes. One would say, well, there's the discourses of the arts, and that's one kind of discourse. Then discourses of the historian. There are the discourses of the philosopher. And then of course one would collapse all the distinctions one is making.

Readings : Even in litterae humaniores, you have a general motion of writing that governs... or of letters, let's say, that governs this, so that (I don't know elsewhere but in England) history emerges as a discipline only very very late, just a little bit earlier than English, and it emerges as moral history, as a sub-branch of philosophy, where it basically attempts to thematize something that had always been done in the study of the classical texts, in litterae humaniores, namely the study of the lives of famous men in order to draw from them moral lessons. And that is how history opens itself, opens up as a discipline.

Krieger : You mean there never was a discipline that studied the art of writing histories, I mean from Herodotus on?

Readings : Not as a university discipline... 
Krieger : That's what I said, that there was no study of historical texts.

Readings : There was study of Herodotus and of Xenophon, but they were studied in a field of textuality.

Krieger : You didn't have Herodotus to Gibbon as a genre?

Readings : No. It began straightforwardly as, you know, this moral question. And you would study historians and their capacity to make moral judgments on histories they related. That was obviously a part of it. But the point is that something happens to a field of writing, and it gets cut up into the humanities. And in some senses I want to say it's not necessarily something that happens entirely to the benefit of a certain attention to language. One of the things I see happening is the return to a kind of more widely textualized account of the field of writing, and a less disciplinary one. I live nextdoor to a department of anthropology, which is a very peculiar experience, because we are a small department, we live on a square, and they kind of embrace us, if you can imagine, they're like a pincer movement and we're caught in their claws. And in one claw are the anthropologists, who do fieldwork of the most straightforward sort, of the kind that you would think of Malinowski - some of them are disciples of Malinowski, some of Levi-Strauss. This is fine; we have interesting discussions with them about the problems of writing culture, and we talk about James Clifford, and whatever. At the other end of the claw, which is still the Department of Anthropology, is where they have people who measure skulls.

Yu : Skulls.

Miller : Bones people, right.

Readings : And because there is actually no Department of Archeology in my university, which is a sort of odd cutting up, you have this very strange effect, because they don't talk to each other across these lines...

Krieger : An American academic would say, well, the second ones are really archeologists, and therefore there should be no common language between them.

Readings : The danger, though, is that you split very easily into someone like Wolf... (I don't know how you pronounce his name, and I've tried to teach him in French, which caused great troubles for me) but it's a name like Le-pi-nese. Anyway, Wolf Lepinese is someone 
who proposes social sciences as the orientation that will unite the study of factual research and the study of value or orientation, and somehow there will be a synthetic fusion of the two. There's this strange desire to find a disciplinary name that will somehow fuse and orient everything that we do. That is to say, precisely to turn that gap, or aporia, or difficulty into the site of the synthesis, and to suddenly make knowledge humanistic in the sense of somehow present to itself in its own humanity. And that seems to me to be a temptation one should resist quite strongly...

Derrida : You are in the same building ...

Readings : Yes. You have a building, and we have lots of historical buildings, we have a campus, we have universities that exist, like in Italy (I was talking to someone else about this), you have cities which have strange places in them, which are very interesting places to live in, in my experience, in a way that Switzerland is not a very interesting place to live. This has to do with the way in which people are subjects in those spaces, the way in which they are not primarily civil subjects in that kind of space.

Yu : You can give Irvine as the counter-example.

Behler : Well, I just wanted to ask something to our Chinese colleagues, Pauline and Ching-hsien Wang, but it's out of context - we are in the Renaissance, It was still concerned with the Chinese notion of humanism.

Derrida : Excuse me. Just one thing. This reminds me that I had a question just a matter of translation into Chinese. How do you translate something like Aufklärung?

Wang : Ch'i-meng. Well, I actually translated a chapter from a booh on the Age of Enlightenment, and I used the term Ch'i-meng.

Derrida : Enlightenment and Aufklärung, as you know, it's not the same. That's the problem. Illuminismo is something else, and lumière is not Aufklärung, so you have one and a single word.

Wang : We have two different words, two terms. One is Ch'i-ming, and the other one is Ch'i-meng. Ch'i actually means "to open."

Derrida : My question was not simply a linguistic one, but is there anything in the Chinese tradition which 
would correspond to this word, that is, a domestic use of the word Aufklärung?

Wang : I would say that it's the departure from the primitive society, with excessive sacrifices and rituals, and the beginning of the Confucian teaching of the people. In our study of ancient poetry, history, and philosophy we constantly run into a term Chün-tzu., which in the original, ancient poetry, Shih Ching, denotes people of a special class, the noble people. Confucius uses that term and emphasizes that, everybody can be a Chün-tzu, meaning that even if you are from a poor family you can still become Chün-tzu.

Yu : It becomes redefined from a class concept to a moral concept.

Birus : You said there is no corresponding thing like "humanitas" and "divinitas." But is to be well educated part of the meaning of "humane" or "human," as opposed to "barbarian?"

Yu : Of course. Yes, very much so. And I think that the secularization is, if one can call it, the analogous movement is simply one that involves taking responsibility for one's actions, as opposed to blaming them on fate, an arbitrary fate. That's the humanist...

Behler : I think that's the idea of autonomy.

Yu : Yes, it's not a divinity or a deity who is, you know, who is sort of...

Krieger : Any arguments on freedom of the will related to that?

Yu : No, it's responsibility; it's not...

Behler : I want to pursue this idea of a nonemancipatory type of humanism, that is not secularized. I remember, fifteen years ago, Ching-hsien Wong and I discussed humanism at meetings on the humanities, and I presented something on this idealistic type of humanism, German Idealism, and the idea of a full development of all human potentialities to a harmonious personality, and the Humboldt idea of education and universality. You told me that would perhaps come closest to...

Wang : I think that humanism became definite, with the open instruction from the master, because before him teaching and knowledge had been monopolized by a 
certain kind of people, and when Confucius taught students, he touk anyone who would volunteer to learn.

Derrida : And knowing how to write, is it linked to this...?

Wang : I would say so, yes. And also the gradual dying out of folk songs with women as the speakers. You know, in the first Confucian anthology of poetry, the Shih Ching, there are so many songs from the woman's point of view. But later on women don't seem to be as active in the making of Chinese literature.

Yu : They become allegorized then.

Miller : It turns out they're really about men.

Yu : They're all about men, yes, all the officials who are remonstrating...

Birus : I would like to put the stress on a problem that is not really well represented in the Begriffsgeschichte. That is the question of the progressivity of humanism. In the quotation from the young Marx on page 4, there is an absolutely utopian dimension of humanism. In the former GDR Constitution, however, you see humanism connected with traditionalism. It's not only the question of the change of of the function of Marxism in Soviet Marxism as described by Herbert Marcuse (I think it's one of his best books). That now the Soviet system presented itself as the institution that will collect all values and all things in mankind's history that are worth of surviving. But, as is quoted in Volume 3 of the selected writings of Roman Jakobson, Grammar of Poetry, and Poetry of Grammar, there were some colleagues here in the United States from the so-called "humanist" camp who opposed against structuralist 'dehumanization,' and such things. So we should look for the present use of this word, if it not often implies resistance against modernity. Isn't "humanist" often a label for good old-fashioned values?

Derrida : Humanism versus materialism.

Birus : Yes.

Krieger : Although, of course, for the young Marx, it was anything but. It was a new and progressive utopist view, where finally that terrible fracture that Kant had made between nature and freedom, and between the natural and the human, was finally wonderfully resolved into this union that, of course, comes to be reflected in a parodied way by the Soviet Union. 
Birus : But you understand my uneasiness.

Krieger : But that was the young Marx.

Miller : Well, that was exactly... One of the things that Hendrik has just been talking about was one of my questions, that we hadn't talked enough about the opening of your paper with the references to the GDR (which is very interesting, that Article 18, paragraph 1), and then the quotation from Marx. You go on to observe, however, that Marx logically proceeded to sacrifice the term "humanism." That is to say, as for Heidegger later on, it becomes a contaminated term that is no longer to be used. On the other hand, later Marxists revive the word, and it becomes a powerful, powerful aspect of the Communist ideology. That is, you couldn't really have communism without the word "humanism," as you have it cited here. And that's related to a question I had for our Chinese colleagues, and that is whether Marxism has translated into Communist China, whether there's any problem... whether you might say there isn't any problem, or much problem, because you have a word already for "humanism," and you could put something like this Article 18, paragraph 1, into Chinese without any problem? That's my question. The question is, what happens to that aspect of Marxism when it gets into China? And that's related to a very specific question, which is structure of the Chinese Academy of Social Sciences in Beijing. That's where the study of literature is now located. The Institute for Foreign Literature is not in some separate humanistic institute at all. It's part of social science. It's a fulfillment of Bill's model of the social sciences as...

Wang : That's right, you're right, yes.

Yu : Yes.

Wang : I forgot about that.

Miller : No, no. That's where it is. And there isn't any humanistic academy. It doesn't exist as a separate entity in Communist China. So what you're telling me is that that's not Confucian. That's communist...

Yu : That's from Russia.

Miller : That's from Russia. That's what I think.

Wang : Many things got cut off from the old China in around 1950. Everything changed. 
Krieger : It's interesting that you speak of the young Marx. We remember, Hillis, you and I, when we were in Moscow last, Barbara Smith, in the spirit of the postmodern, attacked the whole Frankfurt School, and most specifically Herbert Marcuse for being a nineteenth century Marxist humanist.

Miller : That was a nasty word for Barbara Smith.

Krieger : Yes, it was. Marcuse, Adorno, I mean the whole Frankfurt gang. And I think what she was associating with them was a notion that would include the aesthetic and a capacity to deal with the arts as aesthetic without any collision between the aesthetic and the political. All the kinds of collisions that we would expect from recent theoretical quarters would not exist in the thinking of the Frankfurt School. Adorno, of course, most especially.

Birus : Was she an Althusserian?

Miller : No, I think she would be more... it would be more in the name of Jakobson and some kind of scientific study of language, more like "The Poetry of Grammar" kind of attitude - these soft humanists want to get values, talk about people, and so on, whereas I Barbara Smith want to talk about objective linguistic structures, which...

Iser : I think it was mentioned in this very room, or at least in a critical theory debate (Hillis may perhaps remember it) - that to be a humanist is worse than being a racist.

Derrida : In the same spirit, if I may indulge in my Moscow memory... anecdote, four years ago, I was giving a lecture at the University of Moscow. It was precisely the lecture you heard here in Irvine a few years ago. There was a huge crowd, and in this lecture, I quoted Marx, precisely the text in The German Ideology where Marx says he is ironical toward Feuerbach because Feuerbach still remains a German nationalist, a German socialist, criticizing the French and the Belgian socialists in the name of man. So only the German socialists could really build a human socialism, a socialism which would be exemplary for humanity as a whole. So it was at the same time, as is often the case, nationalist, cosmopolitan... universalist, and so on, and socialist. Socialist, nationalist, German. And of course Marx is very powerful when he says, well, here we have a nationalism of man, of mankind, or a nationalism of the 
essence of man. So I mentioned this text by Marx, saying, well, that this is a very lucid analysis of this exemplarity, this scheme of exemplarity of this nation, and we have the responsibility, we are the best witnesses, the most responsible witnesses for mankind, for the humanity as a whole. So I put this on Marx's credit for a while - five minutes - and at the end of the lecture, I received at the table (if they object, they send you notes, as you know)...

Derrida : In Russian or in English. I counted twenty objections: How can you quote Marx here? Don't you know that we have been experiencing a national socialism for seventy years? So everyone was angry at me because I referred to Marx in Moscow in this university. Lenin was still on the wall. So as you know, it is not often the case that I quote Marx, at least at the time.

Krieger : Except in Riverside.

Derrida : And so I became angry in my turn, or I feigned to be angry. Well, I told them... A very huge crowd, where my colleagues, new perestroikan colleagues, were also agreeing with the crowd, asking... presenting objections. I said, well, I resisted Marxism in my own country when it was hegemonic, and when everyone wanted me to refer to Marx and to make... Now... It's not now that I will simply obey another dogmatism. So strange situation, to quote Marx in Moscow and to be...

Krieger : You have to insist on it.

Behler : Since we are talking about this subject matter, which has been on my mind for a long time, maybe I can ask this question. It is striking, of course, that Heidegger, after `45, `46, quotes Marx in the "Letter on Humanism." And he does not only quote him, he is very positive about him... I don't have all these texts present, but from that period I could give you four or five other texts in which he does the same, and puts a very positive emphasis on Marx. Marx is the one who understands history, for instance. And he has other arguments. Is there a reason for that, and why later he disappears completely from his text?

Derrida : Even at that point, his praise of Marx is ambiguous. He says he is a metaphysician - not a metaphysian of matter; he's not a materialist. He's a metaphysician of work. He determines being as production and work. He says we have to take Marx seriously, because he is a great metaphysician. 
Birus : But Ernst, maybe (and I'm inclined to think so) these are not direct references to Marx. I don't think that Heidegger had works of Marx on his bookshelf, but he knew quite well articles on Marx by his former student, Herbert Marcuse. Heidegger obviously follows Marcuse's interpretation of the early writings of Marx. There the guiding line for Marcuse was the selfalienation, and then the topic of labor. Heidegger followed in this respect Marcuse, and so he found the right distance to Sartre. I'm not sure that he ever had read Marx. Why should he?

Krieger : I would address this to the table at large, but since you're the speaker, I address it to you. You've given us more meanings of "humanism," "humanities," and so on, than anyone else, although we've been trying to help you accumulate them. What do you want us to do now with our title and with our project? That is, in what way is anything that we're saying helpful?

Birus : Well, I understand your question, but I cannot give you any advice because at first it's a question of your language. I speak here only in a very barbaric manner as a foreigner, and so I don't think...

Krieger : It's an international center. There is no foreigner here.

Birus : But also of how to use a language, and this is difficult to prescribe.

Krieger : What do we mean?

Birus : Well, must we mean what we say? But I would say, why not use this word? But then we should have to clear about what we don't want...

Krieger : One thing I should add is, when we created the title, we talked a little bit about whether we meant singular or plural, and we put it in the plural, of course. In these days of diversity and the rest, we must have "humanistic discourses." But that would suggest, of course, that mere plurality saves us not having to worry about what "humanistic" means.

Birus : Is it better to say "discourses in the humanities," or maybe "humanities" has less impact because it's...

Krieger : It's partly academic. 
Yu : It's totally academic, yes. I mean, the other problem is, of course, that asking the question this way, you know - do the humanistic discourses also... what are the humanist discourses in other cultures? or whatever begs the question that we're asking, because it sets up certain terms that we assume are going to exist...

Krieger : That's the point, yes.

Yu : ... and I'm really uncomfortable with that.

Derrida : ... a German, for instance, or Chinese...

Krieger : Or Chinese?

Derrida : We would have to find something which would be already translatable.

Krieger : You can't translate it.

Yu : We really can't, I mean...

Krieger : When we're supposed to be opening to East Asia, then it's a perfect example of translation as a problematic.

Derrida : It's not translatable in any language...

Krieger : Except that we impose...

Derrida : ... not French, not French, not German, not Chinese. There is no French equivalent to "humanistic discourses." I don't see how... what would be the French equivalent of "humanistic discourses."

Krieger : And even worse, we're supposed to be opening to East Asia, and of course we're imposing on them our academic categorization which they've got to fit.

Birus : If you drop it, why did I do my work?

Iser : Well, I mean, the term has sufficient latitude so that our conference will give it a new connotation. That's the job we are supposed to do.

Krieger : And if we take the plural of the "discourse" seriously enough, "discourses," name your own.

Derrida : My suggestion would be, if this adventure continues... to change the title each time. That is, this will have been the title of this session. We have to find a 
German title, or a French title, or a Chinese title, and adapting the unspeakable idea...

Krieger : But there's no sense...

Derrida : ... We have some notion of what we want to do. That's what I assume. And we should translate this idea according to the history and the language of the nation or the state, the nation-state, which welcomes the conference. So in Germany it would be something different but connected, given the results of the previous meeting. We have made some steps, and according to this, the next meeting would bear another title, collecting the memory of this one and adjusted to the history of the German language, the German idiom.

Yu : Chinese.

Derrida : Chinese.

Krieger : But what are the ten of us members of? What are we the core group of?

Derrida : Of the future. Of what's waiting for us at the end.

Krieger : It's hard to apply for grants that way.

Derrida : The Other is signing.

Birus : Why not change the title, not as a mere replacement, but by adding the next title with a dash, for instance: "Humanistic Discourses," dash, and then two Chinese or three Chinese characters, not as translations, not as synonyms, but as word for institutions, and so after the next dash: Geisteswissenschaften. And the problem is exactly the spaces between.

Derrida : I imagine that in fact, whatever language we choose for the title, the spoken language will remain English, no?

Miller : I've thought of that more than once here...

Yu : We have more non-native speakers of English than...

Derrida : So we have to reflect on this.

Birus : This title is only provisional, it is only...

Iser : Our preference then will be to bridge that space between, to negotiate the space between "humanities," 
"Geisteswissenschaften," and whatever it may be in Chinese. It's a new subject.

Readings : I want to just sort of cheer everybody up a bit for once by saying that the word "humanistic" is an interesting one in English because I was jokingly saying it's not British. In some sense it's not an English word, and I like that about it. Hendrik has given us an archeology of "humanism," and one of the things it shows is that the word "humanistic" is not the same thing as the word "humanism," that we don't quite know what "humanistic" means. And I would go further and say that the "-ic" functions almost... that suffix functions almost like quotation marks.

Behler : Like an estrangement.

Readings : It does something strange to it. It reminds us

Krieger : Adjectives are better than nouns.

Readings : You can think of yourself as a human... I think what the word "humanistic" does is remind us that you can't be human and a humanist at the same time, and the dangerous people are the people who think you can, you know, because they tend to...

Krieger : But Bill, you know, if you have the word "humanistic" around for two weeks, someone will renominalize it by speaking of "humanistics." We are all students of humanistics.

Miller : That's here. That's a word.

Krieger : "Humanistics" is a word?

Miller : Yes, sure.

Wang : I think I would be able to translate "humanism" into Chinese, and "humanities" is manageable. But I really don't know how to translate "humanistic." But maybe this is the purpose our discourses now in session.

Behler : You can create a monster.

Readings : "Humanistic" has this specific philological sense of a problematic historical recovery, not the discovery of an essence.

Krieger : And "humanities" is so strictly catalogued, as university catalogue jargon. Therefore you prefer this adjective, "humanistic." 
Iser : So far we have been very much opposed to subscribe to any cognitive umbrella concepts. Why on earth do we now head for one. Cognition, I thought we had agreed upon, is not everything, and all of a sudden we seem to be gesturing for an umbrella concept which is basically cognitive.

Krieger : Jacques is saying we don't need a cognitive umbrella.

Iser : And yet we seem to be trying to establish a stance for subsuming our diversified observations.

Krieger : But there is no university or public agency for whom we would ask funding who will not think that we are a body, that we constitute a body, and because of the logocentric character of our title.

Derrida : In the $O E D$, not only do you have "humanistics," "-t-i-c-s, " you have "critical humanisticks," "-t-i-c-k-s," "sticks"!

Miller : That's eighteenth century.

Krieger : That's like "rustick."

Miller : Yes, but that's an interesting quotation: "Pomey's Onomasticks, and Tachard's Lexographicks, and Rapin's Critical Humanisticks... are far surpass'd by our Oxford Grammar."

Krieger : Nothing like a liberal dictionary.

Miller : You don't need any of these other things, if you've got an Oxford Grammar.

Krieger : Is our title part of our concern at this point? Only if we remember the ironical way in which we retain it.

Iser : Enshrouded by unspeakability.

Krieger : And we will never try to translate it.

Miller : "And the Others"...

Yu : We might have to take Hillis's title as the title of...

Miller : Right, "the Others," right.

Derrida : "Humanistics and the Others." 
Krieger : At which point the scientists will come knocking at the door as one of the others.

Yu : You know, there's that musical, The Fantastics. We could call ourselves "The Humanistics."

Krieger : With a "k."

Readings : That's fantastick.

Miller : That's a German word. That's one that means more or less the same in German and English...

\section{NOTES}

1. The following quotations can all be found on page 444 of the " $\mathrm{H}$ " volume of the 1971 OED.

Accueil Surfaces | Table des matières | Recherche Surfaces Home Page | Table of Contents | Search

PUM | Livres | Revues | Publications électroniques | Vente et distribution 